\title{
Impacts of \\ Invasive Ctenophores
on the Fisheries \\ of the Black Sea \\ and Caspian Sea
}
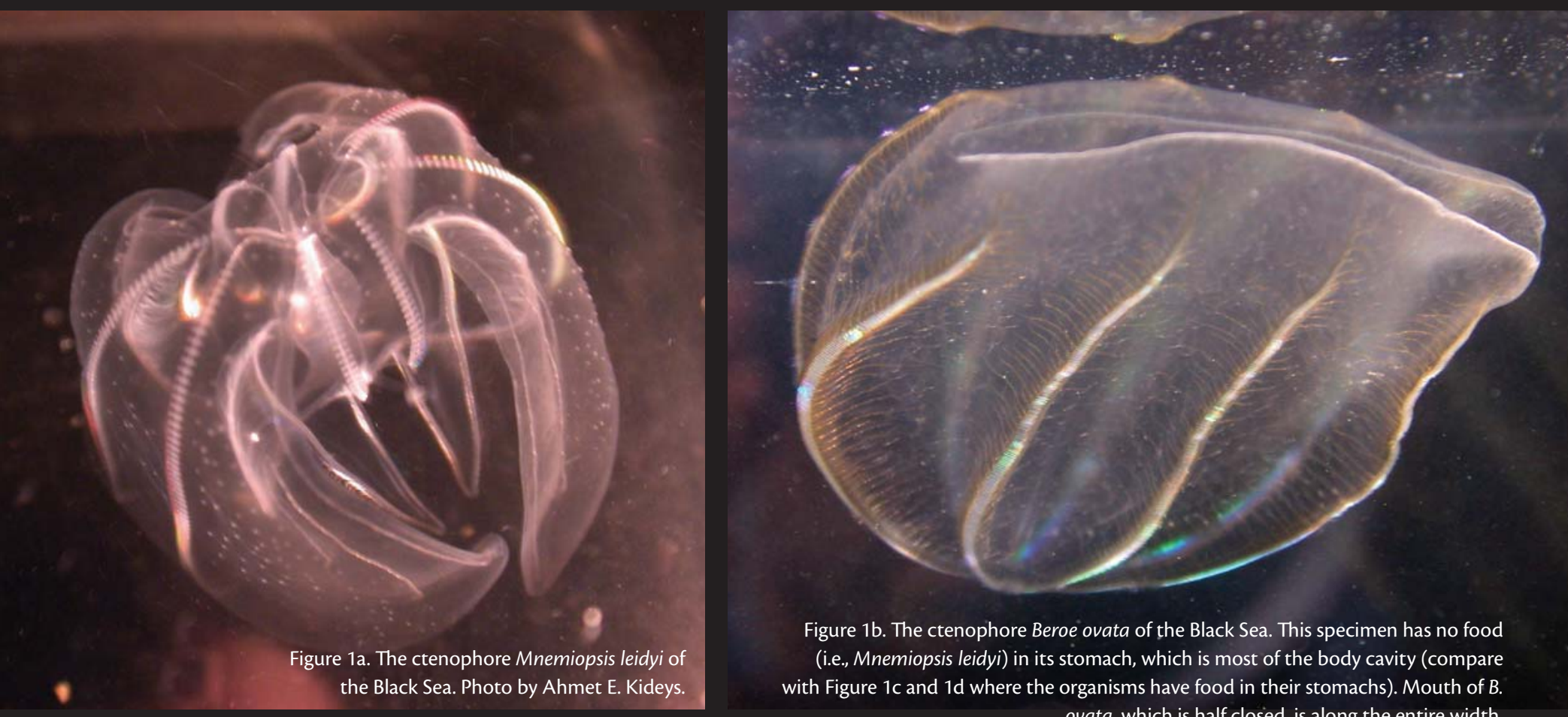

Figure 1b. The ctenophore Beroe ovata of the Black Sea. This specimen has no food

(i.e., Mnemiopsis leidyi) in its stomach, which is most of the body cavity (compare with Figure $1 \mathrm{c}$ and $1 \mathrm{~d}$ where the organisms have food in their stomachs). Mouth of $B$. ovata, which is half closed, is along the entire width. 
Gelatinous zooplankton are known to have a substantial effect on pelagic food webs by exerting topdown control on their ecosystems (Purcell and Decker, 2005), but their impact could be even greater when they invade other regions. The effects of zooplankton invasions have been well documented for the Black Sea and very recently for the Caspian Sea.

Until the 1980s, three species of gelatinous macrozooplankton were present in the Black Sea: two scyphozoan medusae (Rhizostoma pulmo and Aurelia aurita) and only a single ctenophore species (Pleurobrachia pileus) (Kideys and Romanova, 2001). Then, in the early 1980s, the ctenophore Mnemiopsis leidyi (Figure 1a), already known as a voracious zooplankton feeder (Reeve et al., 1978), was transported (likely via ballast waters) to the Black Sea from its native waters of the western Atlantic Ocean. Achievement of peak biomass levels of this ctenophore at the end of the 1980s caused the onset of striking adverse ecological events in the Black Sea, such as abnormal oscillations in plankton dynamics (Kideys et al., 2000) and, most notably, a sharp decrease in the pelagic fishery (Kideys, 1994). By the end of the 1990s, the accidental introduction of another ctenophore to the Black Sea, Beroe ova$t a$ (already known to feed exclusively on other ctenophores) (Figure 1b, 1c, 1d), coincided with another set of striking events, but this time it was beneficial for the ecosystem and the fishery.

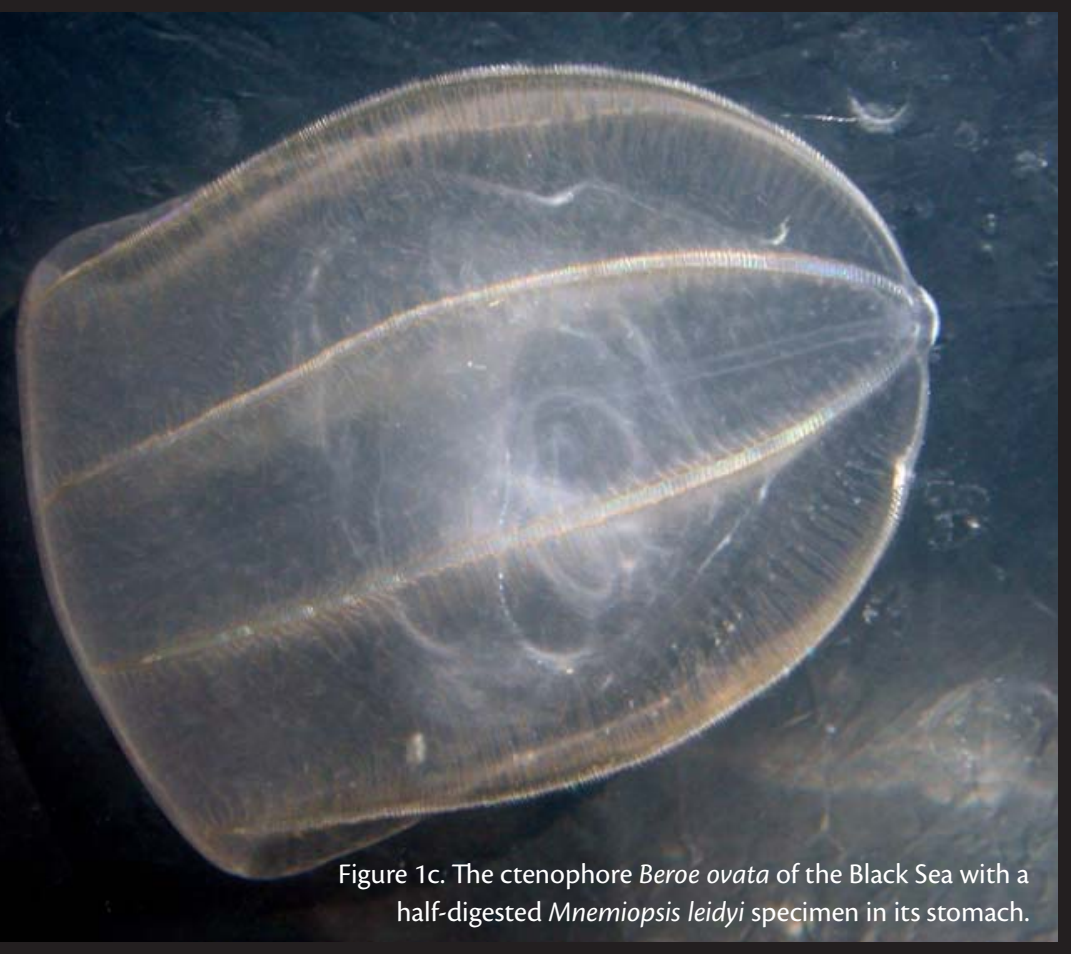

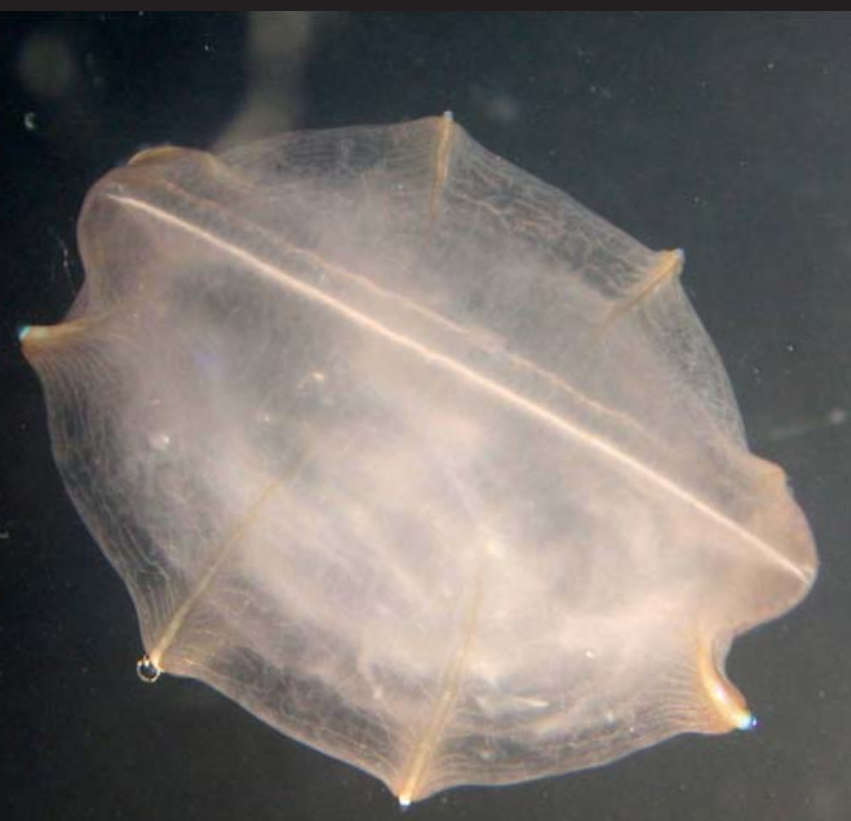

Figure 1d. The ctenophore Beroe ovata just swallowed a Mnemiopsis leidyi specimen in the Black Sea. Photo by Ahmet E. Kideys. 
Invasion of these ctenophores and their contribution to the decline of the entire Black Sea's ecosystem in general, and on its fishery in particular, has been questioned. Other factors, such as overfishing (Gücü and Oguz, 1998; Gücü, 2002) and climate change (see Oguz, this issue) may also be to blame. All of these factors could be acting simultaneously on the ecosystem, however, pinpointing the major ones is very important for understanding sensitive ecosystems that are increasingly exposed to anthropogenic effects and for using the experience obtained from the Black Sea case study to predict, and possibly mitigate, future ecosystem decline. One immediate practical benefit of such knowledge would be for helping to stem the decline of the neighboring Caspian Sea, a unique and fertile ecosystem, which is presently experiencing similar adverse events, but on an even greater scale.

\section{BIOLOGY OF MNEMIOPSIS}

\section{LEIDYI IN ITS NATIVE AND INTRODUCED REGIONS}

Mnemiopsis (Ctenophora) has certain biological characteristics that enable this species to significantly affect its ecosystem. Main (1928 cited in Vinogradov et al., 1989) points out that, although most medusae are microphages (consume microscopic prey), Mnemiopsis is a macrophage capable of consuming fairly large prey (up to $1 \mathrm{~cm}$ or more in length). Mnemiopsis, like all other ctenophores, are hermaphroditic. Ctenophores, particularly members of the genus Mnemiopsis, have a very high reproductive capacity. Mnemiopsis mccradyi is able to produce 8,000 eggs within 23 days-after only 13 days of its own birth. The growth rate of this species is comparable to that of phytoplankton (daily doublings) (Reeve et al., 1978). Such high growth rates can only be achieved with a very high feeding rate. The abundance of Mnemiopsis has been observed to fluctuate throughout the year. In the Narragansett Bay (offshore Rhode Island, USA), for example, Kremer and Nixon (1976) found that while the overwintering population of Mnemiopsis was extremely low (1 to 2 animals per $10^{4} \mathrm{~m}^{3}$ ), they could reach a peak density of over 50 individuals per $\mathrm{m}^{3}$ in summer. Although highest abundances occur in summer (and early autumn), unlike in native regions, relatively high concentrations of this ctenophore were present during other seasons in the Black Sea (Mutlu, 1999; Kideys and Romanova, 2001). It is worth noting that Mnemiopsis's main summer spawning period coincides with that of the anchovy in the Black Sea.

Mnemiopsis has long been reported as an effective predator on zooplankton. Reeve et al. (1978) state that perhaps the most significant aspect of the feeding behavior of Mnemiopsis is that their ingestion rate is proportional to food concentration. Because of this, concominant with their appearance, a dramatic decrease in the number or biomass of copepods and other food zooplankton is often observed in the native region. For example, Burrell (1968, cited in Kremer, 1979) suggested that predation by $M$. leidy $i$ was responsible for a large fraction (73 percent) of total zooplankton mortality in the York River estuary of the Chesapeake Bay (offshore Virginia, USA). Finenko and Romanova (2000) calculated that on a daily basis, about 20 percent of total forage zooplankton was being eaten by this ctenophore in the summer of 1995. Similar high values were found by other scientists studying the Black Sea and Caspian Sea (Finenko et al., in press). M. leidyi has also been shown to feed on the eggs and larvae of fishes both in its native region and in the Black Sea (Mutlu, 1999).

In the Black Sea, M. leidyi (as well as Aurelia aurita and Beroe ovata) are confined to surface (and mainly coastal) waters above the thermocline (in the warm seasons) (Mutlu, 1999; Kideys and Romanova, 2001) coincident with the greatest abundance of zooplankton (due to smaller copepod and cladoceran species as well as young stages of other important forage zooplankton). These gelatinous zooplankton are separated from the native ctenophore Pleurobrachia rhodopis, which dwells in deeper (below the thermocline at around $30 \mathrm{~m}$ in summer) and offshore waters.

\section{LONG-TERM DISTRIBUTION OF M. LEIDYI IN THE BLACK SEA}

The biomass of the offshore- (and deep-) dwelling ctenophore Pleurobrachia rhodopis varies less over time (Kideys and Romanova, 2001) than Aurelia aurita and M. leidyi. Figure 2 shows long-term changes in the biomass of only M. leidyi and Aurelia aurita (biomass changes of the most recent ctenophore Beroe ovata are discussed separately later). In this figure, the values obtained until 1991

Ahmet Erkan Kideys (kideys@ims.metu. edu.tr) is Associate Professor, Institute of Marine Sciences, Erdemli, Turkey. Abolghaseem Roohi is Research Associate, Mazandaran Fisheries Research Center, Sari, Iran. Siamak Bagheri is Research Associate, Guilan Fisheries Research Center, Anzali, Iran. Galina Finenko is Senior Research Associate, Institute of Biology of the Southern Seas, Sevastopol, Ukraine. Lyudmila Kamburska is Senior Research Associate, Institute of Oceanology, Varna, Bulgaria. 
belong to Russian investigators (mainly from the western and northern Black Sea), and after 1991, to Turkish investigators (from the southern Black Sea). It should be noted that, although the Turkish data were from a higher number of stations, Kideys and Romanova (2001) suggested these values were too low because their nets were not as efficient (had a coarser mesh) as the Russians'. Because of this, the Russian values were efficiency-corrected (multiplied by 2 to 3 based on the net most often used), though those from the southern Black Sea (after 1991) were reported as uncorrected, raw values. As seen in Figure 2, after the famous peak values of 1989, biomass values for M. leidyi as high as $485 \pm 34 \mathrm{~g}$ $\mathrm{WW} / \mathrm{m}^{2}$ (wet weight per meters squared) were obtained in 1995 (uncorrected, raw data from March, which is not the main development season of this ctenophore!) from a dense station grid (107 stations) in the southern Black Sea (Mutlu, 1999). These data clearly show that the Russian (corrected) values of 1.5 to $2 \mathrm{~kg}$ WW/m² obtained for early autumn 1989 (Vinogradov et al., 1989) are reasonable as opposed to Gücü and Oguz's (1998) statement that, "neither carrying capacity nor the trophodynamic structure of the Black Sea support such high biomass value of Mnemiopsis sp."

It has been suggested that, since the 1970s, the population of A. aurita has been increasing, reaching peak values in the 1980s (Figure 2). After the explosive development of M. leidyi in 1989, the abundance of A. aurita dropped precipitously (Figure 2), indicating a potential for intense competition between these species. One should note here that, given the same biomass, $M$. leidyi would exert a much higher impact on the ecosystem compared to A. aurita due to differences

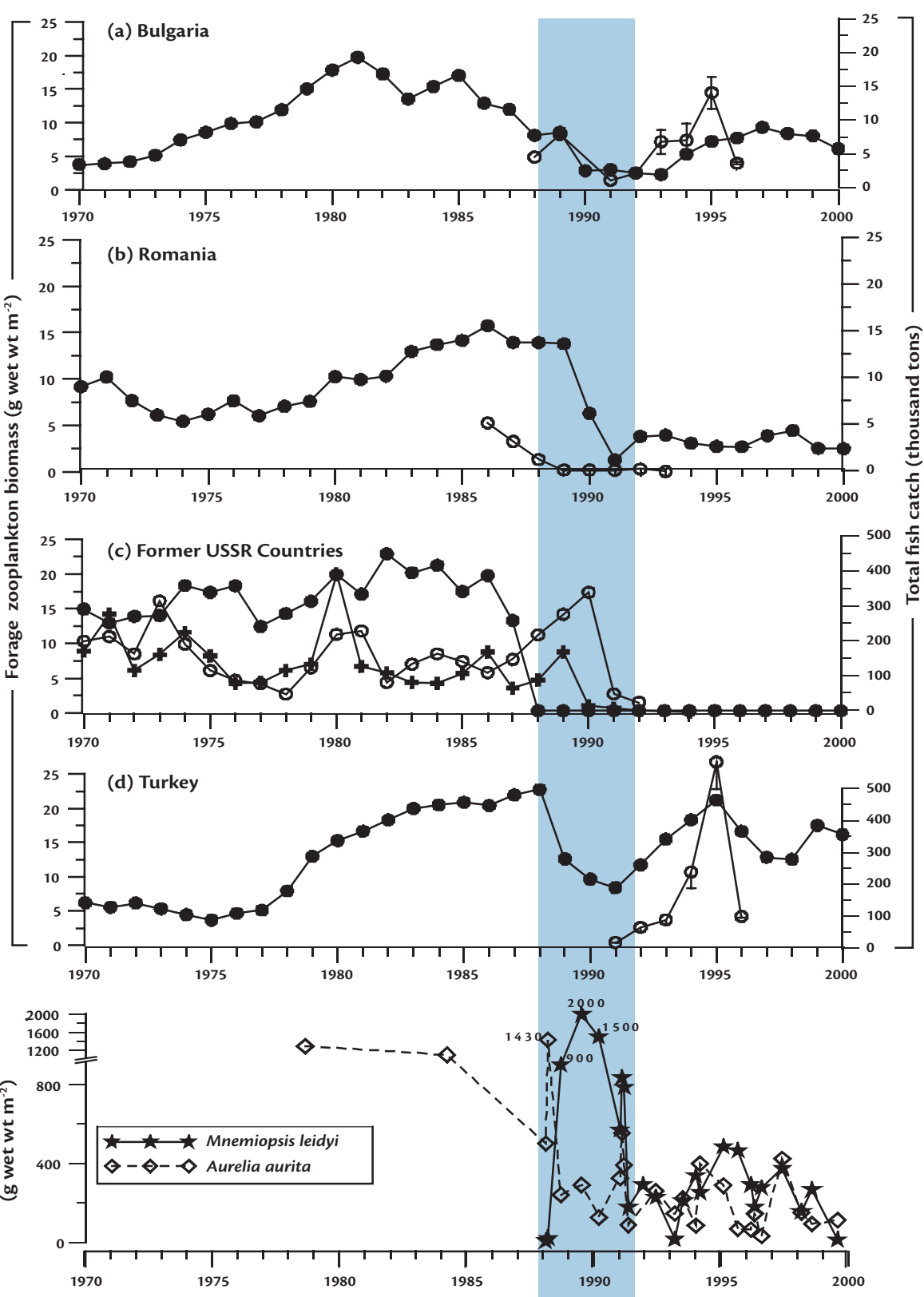

Figure 2. Long-term changes in the biomass of fish, forage zooplankton, and gelatinous macrozooplankton in the Black Sea. Fish catch data for each country is from www.seaaroundus. com. The forage zooplankton data (from Kideys et al. [2000], except for Romania) are for (a) from the offshore western Black Sea, (b) from the coastal waters off Romania (from A. Petran and M. Moldoveau, National Institute for Marine Research and Development "Grigore Antipa" Constanta, unpublished data, 2005), (c) from the coastal northwestern shelf $(+)$ and offshore waters of the northeastern region, and (d) from offshore waters off Turkey. Gelatinous zooplankton data before 1991 belong to the northern Black Sea (Russian values), and after 1990 belong to the southern Black Sea (Turkish values, after Kideys et al. [2000]). Note the blue rectangular area where the first peak of Mnemiopsis leidyi occurred, when there were sharp decreases in the fish catches and forage zooplankton in different regions.

in their physiological rates (e.g., feeding, reproduction, and growth).

The first appearance of M. leidyi was reported in 1982 in the western Black Sea (Konsulov and Kamburska, 1998) and its biomass peaks in 1988 to 1989 , 
six years later. Considering the extremely fast reproduction and growth capability of this ctenophore, this period is long. However, since M. leidyi is known to prefer higher temperatures for reproduction, such a delay may be due to the unusually cold temperatures observed in the Black Sea occurring during those years (Oguz, this issue).

After the highest values were reported between 1988 and 1991, the biomass of M. leidyi oscillated at more moderate levels, with a secondary peak in 1995. Given the lack of predators (until 1997) and parasites, one of the most important factors for the decrease in the biomass of M. leidyi was likely to have been food limitation: glycogen storage is the main mechanism for energy accumulation in ctenophores. Under conditions of starvation, glycogen levels in these animals decrease. Data on the body glycogen content of M. leidyi from the offshore waters in September 1996 recorded levels between 21 and $44 \mu \mathrm{g} / \mathrm{g}$ wet weight (Anninsky et al., 1998). Thus, the condition of $M$. leidyi obtained from field samples corresponded to that expected after a two-day fasting period (determined experimentally), implying that the ctenophores were starving. The decrease in $M$. leidyi after its major peak also could have been influenced by the cooler climatic period observed between 1992 and 1995 (Oguz, this issue), as this ctenophore prefers warm temperatures for spawning.

One important aspect of the temporal distribution of M. leidyi until 1998 was that relatively high biomass values of this ctenophore could still be obtained by cruises during the colder months. However, the very low average biomass value of $12 \mathrm{~g} / \mathrm{m}^{2}$ observed in the main spawning month of September 1999 was very striking for the scientists investigating the distribution of this ctenophore in the Black Sea (Kideys and Romanova, 2001). In fact, this is the lowest average biomass value recorded for $M$. leidyi since its mass development in the southern Black Sea. This clear decreasing trend (Figure 2) and the strong seasonality (Figure 3 ) observed after 1998 appears to follow the arrival of the M. leidyi predator Beroe ovata to the Black Sea (more on this in later sections).

\section{THE ROLE OF MNEMIOPSIS LEIDYI ON THE DECREASE OF ANCHOVY CATCHES}

Fish-catch data are some of the most important indicators of an ecosystem's condition. Therefore, the analysis of fishcatch data presents important clues to understanding the role of different factors in ecosystem change. The anchovy (Engraulis encrasicolus) is the most important fish species in the Black Sea, both in terms of biomass as well as in economic terms. Between 1950 and 2001, more than 60 percent of the total catch in the Black Sea had been that of anchovies (more information available at http:// www.seaaroundus.org). Turkey and the former Soviet Union were the two major fishing nations in the Black Sea until the late 1980s. Since then, Turkey's fish catch has been the highest in this region (Kideys, 1994), which has defined an Exclusive Economical Zone for each riparian country. One interesting aspect is the sharp decreases in anchovy catches observed at the end of the 1980s for all countries. These decreases in fishing levels in most bordering countries correlate well with the peak levels of the introduced ctenophore M. leidyi (Figure 2).

Despite such a correlation, following an ecological modeling exercise, Gücü (2002) claimed that, "The budget calculations suggest a minimal role of gelatinous species on the decline of the fish stocks, contrary to the general belief. More interestingly, the model results indicate that the decline in the fish stocks was as a consequence of overfishing...” We disagree with this statement. It would be too much of a coincidence that all countries overfished during the same period. One expects that overfishing, if any, should be at its lowest level for the Soviet block countries during this time; at the end of the 1980s, they were experiencing the worst economic (and political) instability of the last several decades.

One could argue that while most of the fish species are non-migratory, the anchovy may be migrating and hence any potential overfishing by Turkish fishermen may have an effect at the basin scale. There are two subspecies of anchovy in the Black Sea: Engraulis encrasicolus ponticus, which mainly dwells in and around the Azov Sea area, and Engraulis encrasicolus maeticus, which is found throughout the Black Sea. E. e. ponticus is reported to undertake basin-scale migrations between different regions in the sea (Ivanov and Beverton, 1985); however, spawning data from the entire Black Sea coastal region (Niermann et al., 1994) indicates that this anchovy could well be a non-migratory fish. It should also be noted that catches of other small pelagic fish species (e.g., Sprattus sprattus, Clupeonella cultriventris, and Trachurus mediterraneus) also plummeted sharply during this period (Kideys, 1994). Even the catch of all small pelagic fish species from the Sea of Marmara showed the sharpest decrease in 1989. This sea was likely also invaded by the ctenophore M. leidyi during the same period as the Black Sea; strong surface currents exchange water between these species. 
Two of the major indicators of overfishing are related to fishing effort and mean size of the fish. During the period of sharp decrease in anchovy catch, there was no sharp increase in the effort spent fishing for anchovies (see Figure 3 in Gücü [2002]). In 1988, the very large mean size of an anchovy was $11.3 \mathrm{~cm}$ just before the fishery collapsed. This large size is a good indication that the southern Black Sea was not significantly overfished. There was, however, a sharp decrease in mean size of anchovies caught after 1988 (down to $7.4 \mathrm{~cm}$ in 1990) (Figure 4), along with total catch. However, this size decrease is mystifying. Rather than overfishing, this decrease must be mainly due to the invasion of M. leidyi. While the anchovy population was declining due to malnutrition (M. leidyi were eating their way through the anchovies' normal prey), fishermen were trying to maintain the fish catches they had secured in the previous few years (i.e., mid 1980s). Applying the same fishing effort to a smaller fish stock would inevitably result in a decrease of the mean fish size as was suggested by Bingel et al. (1993). So, if there were no $M$. leidyi in the ecosystem, the mean size of the anchovies caught would not necessarily decrease sharply.

Another piece of evidence (and possibly the most important) against the overfishing hypothesis is the sharp decrease in the mesozooplankton population, the food of both planktivorous small pelagic fish and the ctenophore M. leidyi. If there was a significant level of overfishing, one would expect an increase in the biomass of mesozooplankton during this cold period when more nutrients are pumped from deeper waters, leading to higher productivity in the surface waters for the entire basin (Oguz, this issue). Yet, high mesozooplankton
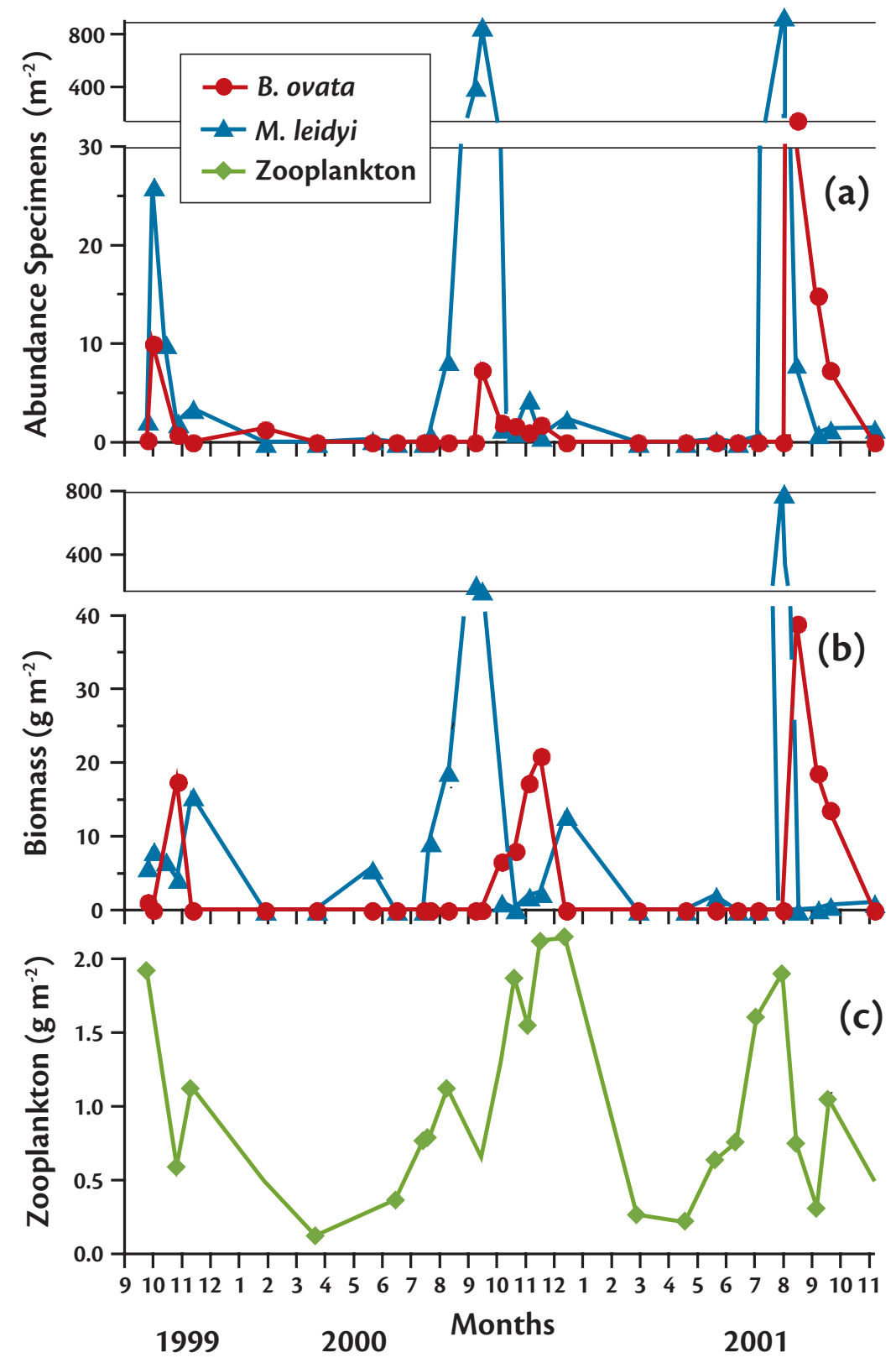

Figure 3. (a) Abundance and (b) biomass of M. leidyi and B. ovata, and (c) zooplankton biomass in Sevastopol Bay in 1999-2001 (from Finenko et al., 2003). Note the predation impact of $B$. ovata on M. leidyi and of M. leidyi on forage zooplankton particularly in 2000 and 2001.

levels were seen only in one data set, offshore of the northern Black Sea (Figure 2c). In the Black Sea, there are a limited number of forage zooplankton species, many of which are well adapted to cold temperatures (e.g., the chategnath $\mathrm{Sa}$ gitta setosa, and the copepods Calanus euxinus and Pseudocalanus elongatus).
These species are also well adapted to large temperature variations, as high as 15 degrees $C$ in a 24 -hour period, because of their vertical migration capabilities. There is no evidence that an overall decrease of about 1.8 degrees $\mathrm{C}$ in winter temperatures from 1980 to 1993 would be detrimental for forage zooplankton as 


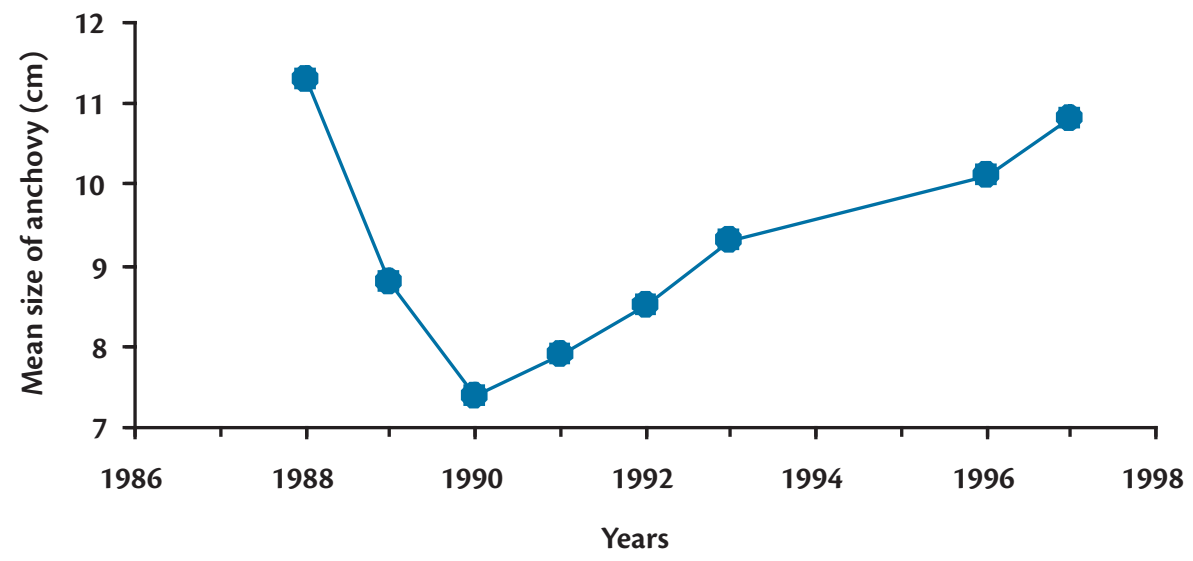

Figure 4. Changes in the mean sizes of anchovy catch population in the southern Black Sea. Data of 1988 to 1994 are from Bingel et al. (1993) and 1996 to 1997 from Mutlu (2000).

implied by Oguz (this issue).

Long-term changes in forage zooplankton biomass show that during the initial peak years (1988 to 1991) of $M$. leidyi biomass, forage zooplankton biomass was generally the lowest for different regions of the Black Sea (Figure 2). Fisheries biomass was also at its lowest levels, or had declined sharply, during this time period. These data correspond well with data on the mean size of fishes. The only exception to these trends was the mesozooplankton of the offshore waters of the northern Black Sea, where high levels of mesozooplankton were still present until 1990, after which they also declined sharply. Note that coastal regions are generally known to have higher productivity and hence larger fish stocks; the biomass decline seen in the inshore mesozooplankton of northern Black Sea (Figure 2) should have played a greater role in the decline of former Soviet Union fisheries through malnutrition of adults and, particularly, younger fish.

The high forage mesozooplankton biomass values in offshore regions in 1989 and 1990 could be due to increased productivity of the ecosystem (Oguz, this issue), the biology of the dominant mesozooplankton species, and the distribution of $M$. leidyi (mainly inshore) (Kideys and Romanova, 2001) and its feeding strategy. Anninsky et al. (1998), after analyzing field data, suggested that the impact of the M. leidyi predation on small copepods, cladocerans, and younger stages of Calanus euxinus was stronger. They explained the high levels of mesozooplankton in 1989 and 1990 were due to late stages of the large copepod C. euxinus, which usually constitutes an important portion of the total mesozooplankton biomass. In later years, due to consumption of the younger stages of this copepod (i.e., recruitment failure), this copepod population also declined sharply. It is also interesting that during the second highest peak of M. leidyi in 1995 (about $500 \mathrm{~g} \mathrm{WW} / \mathrm{m}^{2}$ for the southern Black Sea and as high as a few kg values for the northern regions) (Kovalev and Piontkovski, 1998), secondary decreases in the fisheries of all riparian countries (except Romania) and mesozooplankton occurred (Figure 2).

We suggest that the high chlorophyll levels seen between 1988 and 1992 (see
Oguz, 2005) are also due to the very low levels of zooplankton biomass (consumed by the invasive ctenophore). Similarly, high chlorophyll levels in the Caspian Sea during March 2001 are shown to be due to M. leidyi predation on mesozooplankton (Kideys et al., in press).

The economic losses were substantial from the decreased fish catches particularly during 1989 to 1993 . Assuming a costs of about 1 USD per kilogram of fish, the minimum economic loss for Turkey alone would be more than 1 billion USD. Recognizing the large-scale impact of the invasive ctenophore, the United Nations Environmental Program became involved in order to find a solution to the negative impact of M. leidyi on the Black Sea ecosystem. After reviewing the situation, the Group of Experts on the Scientific Aspects of Marine Environmental Protection (GESAMP) recommended biocontrol as the only viable method of dealing with the M. leidyi problem and, furthermore, suggested another ctenophore, Beroe ovata, as the best biocontrol agent to be used.

\section{THE CTENOPHORE BEROE OVATA AND ITS IMPACT IN}

\section{THE BLACK SEA}

The new alien ctenophore, B. ovata (Figure 1b), first appeared in the Black Sea in October 1997 (Konsulov and Kamburska, 1998), possibly arriving in the ballast waters of ships. During their 1999 cruise, Kideys and Romanova (2001) noted for the first time the occurrence of this M. leidyi predator in the southern Black Sea with an average biomass value of $12 \mathrm{~g} / \mathrm{m}^{2}$. Immediate laboratory experiments (combined with field data) designed specifically to assess the outcome of this new invasive species concluded that B. ovata could effec- 
tively control the M. leidyi population, in particular, and help the dynamics and structure of the pelagic community as a whole (e.g., Finenko et al., 2001; Kideys, 2002). One important aspect of $B$. ovata is that it is observed, both in the laboratory and field, to feed exclusively on $M$. leidyi (Kideys et al., 2004). Note that the other ctenophore species of the Black Sea, Pleurobrachia rhodopis, is separated from $B$. ovata by depth (the latter being also confined to above the thermocline). Even the larva of $B$. ovata has been observed to feed on M. leidyi (either on its tissue or larva).

Figure 3 shows the abundances, biomasses, and population structures of the two introduced ctenophore species $M$. leidyi and B. ovata, and mesozooplankton, in inshore waters of the northern Black Sea (i.e., Sevastopol Bay and adjacent regions), from 1999 to 2001, following B. ovata's arrival. Unlike to the previous years, very low abundances and biomass values of $M$. leidy $i$ were observed during most of the year, with a sudden increase in summer to early autumn, but only for about a two-month period. The B. ovata bloom during the peak M. leidyi biomass resulted in the biomass of the latter falling sharply to extremely low values. These data show that the introduction of B. ovata to the Black Sea has considerably reduced the numbers $M$. leidyi present. Subsequently, the predatory impact of $M$. leidyi on prey zooplankton was found to be reduced significantly in this period compared with pre-Beroe ovata appearance. The daily energy requirements of M. leidyi accounted for 29 to 39 percent of the zooplankton stock only in September 2000 and August 2001 (period of maximum Mnemiopsis biomass); for other months they accounted for less than 1 percent. These values ranged from 17 to 53 percent of the zooplankton stock during July-October 1995 (Finenko et al., 2003).

After Beroe ovata's arrival, many other positive developments were reported in the Black Sea ecosystem, including increases in mesozooplankton numbers from different regions, in numbers of fish larvae and eggs, in meroplankton quantities, and even in increased dolphin appearances (Shiganova et al., 2004).

\section{LEIDYI IN THE CASPIAN SEA}

The possibility of M. leidyi introduction into other sensitive, neighboring ecosystems, notably the Caspian Sea, had been mentioned during the GESAMP meeting in 1994. As expected, this ctenophore was reported to be present in the Caspian Sea by November 1999 (Ivanov et al., 2000). Ivanov et al. (2000) suggested that this ctenophore was transported via ballast water taken aboard either in the Black Sea or the Sea of Azov (where M. leidyi occurs in the warm months) and released after ballast-loaded ships had passed through the Volga Don Canal and the shallow, freshwater areas of the northern Caspian Sea into the saltier central or southern Caspian waters. This species invasion was the start of one of the most important anthropogenic problems the Caspian Sea ecosystem has ever seen. This event can be classified among the largest impacts from an invasive species in any of the world's seas.

Several basin-wide surveys were undertaken to understand the distribution of M. leidyi in the Caspian Sea (Shiganova et al., 2001; Kideys and Moghim, 2003). In August 2001, a comparison of data from different depths revealed that $M$. leidyi were generally confined to surface waters. The maximum size of the ctenophore was only 41 to $45 \mathrm{~mm}$, and the bulk of individuals ( 85.5 percent) were less than $10 \mathrm{~mm}$ in length (much smaller than the Black Sea population, perhaps due to lower salinity of the Caspian Sea). The average and maximum biomasses of $M$. leidyi were calculated as 120 and $351 \mathrm{~g} \mathrm{WW} / \mathrm{m}^{2}$, respectively. These figures showed that this ctenophore population expanded much faster in the Caspian Sea compared to the Black Sea, which could be related to the warm period during those years (Oguz, this issue). While the highest biomasses were observed in the western and central Middle Caspian Sea, hot-spot reproductive areas were present along the coasts of the western Caspian Sea, with abundance values of up to $2285 \mathrm{ind} . / \mathrm{m}^{2}$ (Kideys and Moghim, 2003). The impact of such high densities of M. leidyi is suggested to be significant for the pelagic ecosystem of the Caspian Sea.

Since 2000, several monitoring stations were set up along the Caspian coasts with the support of the Caspian Environment Program (CEP) and national funding from several riparian states. Long-term data from the southern Caspian revealed a seasonal distribution in M. leidyi quantity, with the highest values in warmer months (Figure 5). Finenko et al. (in press) calculated the seasonal impact of M. leidyi on zooplankton, which was highest in summer due to higher water temperatures and the population size structure; at this time, juvenile ctenophores, with mean lengths of 2 to $5 \mathrm{~mm}$, accounted for most of the population. From winter through spring, these ctenophores were found to consume the available stock of zooplankton in three to eight days, whereas in summer, total population consumption took only one day. Finenko et al. (in press) suggested that such a high 
abundance of ctenophores, if sustained, would maintain the non-gelatinous zooplankton biomass at very low quantities and, consequently, no recovery could be expected in this pelagic fishery.

The Caspian Sea, is similar to the Black Sea in many respects, including sustaining a large pelagic fishery, the main fish of which is the kilka (three species of Clupeonella). Similar to the Black Sea, the most visible impact of $M$. leidyi was on the pelagic fishery (Figure 5). For example, the kilka (Clupeonella $s p p$.) catches of Iran initially dropped to 64 thousand tonnes in 2000 to 45 thousand tonnes in 2001, from earlier 1988 and 1989 values of 82 and 85 thousand tonnes, respectively. Further decreases were observed during 2002 to values of less than 24 thousand tons. So, within three years, more than 70 percent decrease in the kilka catches of Iranian fishermen occurred, with a minimum of 125 million USD in economic losses. Similarly, Azerbaijan and Russian kilka catches also plummeted strikingly during 2000 to 2003 (Figure 5).

During 2000 to 2003, several other adverse events must have occurred in the
Caspian Sea due to top-down effects of M. leidyi consumption of zooplankton, which was observed to have decreased substantially between 1998 and 2001

\section{(A. Roohi et al., Mazandaran Fisheries}

Research Center, Sari, Iran, unpublished data, 2004). Many of the endemic cladoceran species are no longer present in the samples obtained from the monitoring stations. Some large predators that feed on kilka, such as the white sturgeon (Huso huso) and the endemic Caspian seal (Phoca caspica), are now considered to be highly endangered in the Caspian Sea (Kideys and Moghim, 2003). There have already been reports of mass mortality events for the Caspian seal $(\mathrm{H}$. Dumont, Laboratory of Animal Ecology, Ghent University, Belgium, pers. comm, 2004). Although seal mortality is often related to viral infections, we believe that the decrease in the kilka populations contributed to such mortalities. It has also been reported that the percentage of pregnant females among seal populations decreased significantly in 2001 (Shiganova et al., 2001), which could be related to malnutrition.

After the events and investigations carried out in the Black Sea, Beroe ovata seems the obvious solution for the Caspian Sea problem. To evaluate the potential success of Beroe establishment in this environment, several physiological aspects (feeding, respiration, growth, and reproduction rates) of $B$. ovata in Caspian waters were investigated by either transporting B. ovata from the Black Sea into the Khazerabad Fisheries Research Laboratory on the Caspian coast of Iran, or by transporting Caspian water to Sinop (Turkey), southern Black Sea (Finenko et al., 2003; Kideys et al., 2004). The studies' findings showed that after gradual adaptation, $B$. ovata were able to adapt to the Caspian Sea's low salinity (maximum value of 13 ). B. ovata only consumed $M$. leidyi. The feeding rate of B. ovata ranged from 14 to 765 percent of body wet weight and was highest for smaller individuals (i.e., 13 to $16 \mathrm{~mm}$ ). Over the measured weight range, the weight-specific respiration rate was independent of weight. The daily specific growth rate of adult $B$. ovata was 7 to 11 percent of body wet weight. B. ovata spawned, and their eggs were hatched, in Caspian Sea water. Although the larvae

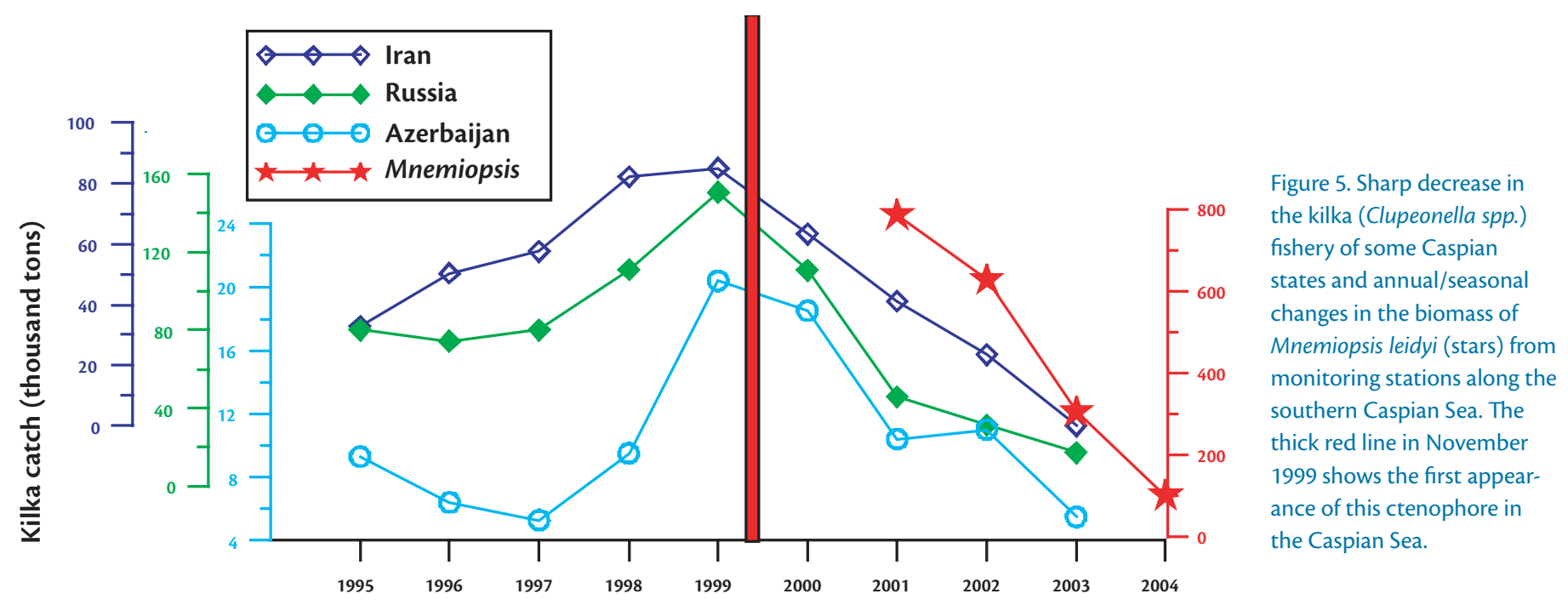


survived for only a few hours in the 2002 experiments, during the 2003 experiments, the larvae survived and subsequently grew over a two-month period. Based on these physiological data, it was suggested that in the Caspian Sea, B. ovata will be able to ingest $M$. leidyi intensively (Kideys et al., 2004) and help the ecosystem to recover significantly. Such a finding is very important for dealing with the invasive ctenophore M. leidyi problem in the Caspian Sea or other regions in future.

The ongoing discussion as to the reasons of major ecosystem changes in the Black Sea should not be seen as futile. Such an exercise in pinpointing the major causes could be extremely important, for example, in dealing with the invasive species problem of the Caspian Sea. The available data presented here suggest that the invasive ctenophores are major influences driving the striking ecosystem changes taking place in the Black and Caspian Seas.

\section{ACKNOWLEDGEMENTS}

We thank the Caspian Environment Programme (CEP) for their support of our studies in the Caspian Sea, to T. Oguz for making his unpublished manuscript available to us, and to E. Eker-Develi for her various help in preparing the text. This effort is a cooperative project of the Census of Marine Zooplankton (CMarZ), a field project of the Census of

\section{Marine Life. 屃}

\section{REFERENCES}

Anninsky, B.E., Z.A. Romanova, G.I. Abolmasova, A.C. Gucu, and A.E. Kideys. 1998. Ecological and physiological state of the ctenophore Mnemiopsis leidyi (Agassiz) in the Black Sea in autumn 1996. Pp. 249-262 in NATO TU-Black Sea Project: Ecosystem Modeling as a Management Tool for the Black Sea, Symposium on Scientific Results, L. Ivanov and T. Oguz, eds. Kluwer Academic Publishers, Dordrecht, The Netherlands.
Bingel, F., A.E. Kideys, E. Ozsoy, S. Tugrul, and T. Oguz. 1993. Stock assessment studies for the Turkish Black Sea Coast. NATO-TU Fisheries Final Report. Middle East Technical University, Institute of Marine Sciences, Erdemli, Turkey, 96 pp.

Finenko, G.A. and Z.A. Romanova. 2000. The population dynamics and energetics of ctenophore Mnemiopsis leidyi in Sevastopol Bay. Oceanology 40:677-685.

Finenko, G.A., B.E. Anninsky, Z.A. Romanova, G.I. Abolmasova, and A.E. Kideys. 2001. Chemical composition, respiration and feeding rates of the new alien ctenophore, Beroe ovata, in the Black Sea. Hydrobiologia 451:177-186.

Finenko, G.A., Z.A. Romanova, G.I. Abolmasova, B.E. Anninsky, L.S. Svetlichny, E.S. Hubareva, L. Bat, and A.E. Kideys. 2003. Ingestion, growth and reproduction rates of the alien Beroe ovata and its impact on plankton community in Sevastopol Bay, the Black Sea. Journal of Plankton Research 25:539-549.

Finenko, G.A., A.E. Kideys, B.E. Anninsky, T.A. Shiganova, A. Roohi, M.R. Tabari, H. Rostami, and S. Bagheri. In press. Invasive ctenophore Mnemiopsis leidyi in the Caspian Sea: Feeding, respiration, reproduction and impact on zooplankton community. Marine Ecology Progress Series.

Gücü, A.C. 2002. Can overfishing be responsible for the successful establishment of Mnemiopsis leidyi in the Black Sea? Estuarine, Coastal and Shelf Science 54:439-451.

Gücü, A.C. and T. Oguz. 1998. Modeling trophicinterrelationship in the Black Sea. Pp. 359-371 in NATO TU-Black Sea Project: Ecosystem Modeling as a Management Tool for the Black Sea, Symposium on Scientific Results, L. Ivanov and T. Oguz, eds. Kluwer Academic Publishers, Dordrecht, The Netherlands.

Ivanov, P.I. and R.J.H. Beverton. 1985. The Fisheries Resources of the Mediterranean. Part Two: The Black Sea. Studies and Reviews, 60, General Fisheries Council for the Mediterranean, Food and Agriculture Organization of the UN (FAO), Rome, Italy, 135 pp.

Ivanov, P.I., A.M. Kamakim, V.B. Ushivtzev, T. Shiganova, O. Zhukova, N. Aladin, S.I. Wilson, G.R. Harbison, and H.J. Dumont. 2000. Invasion of Caspian Sea by the comb jellyfish Mnemiopsis leidyi (Ctenophora). Biological Invasions 2:255-258.

Kideys, A.E. 1994. Recent dramatic changes in the Black Sea ecosystem: The reason for the sharp decline in Turkish anchovy fisheries. Journal of Marine Systems 5:171-181.

Kideys, A.E. 2002. Fall and rise of the Black Sea ecosystem. Science 297(5586):1482-1484.

Kideys, A.E. and Z. Romanova. 2001. Distribution of gelatinous macrozooplankton in the southern Black Sea during 1996-1999. Marine Biology 139:535-547.

Kideys, A.E. and M. Moghim. 2003. Distribution of the alien ctenophore Mnemiopsis leidyi in the Caspian Sea in August 2001. Marine Biology 142:163-171.

Kideys, A.E., A.V. Kovalev, G. Shulman, A.D. Gordina, and F. Bingel. 2000. A review of zooplankton investigations of the Black Sea over the last decade. Journal of Marine Systems 24:355-371.

Kideys, A.E., G. Finenko, B. Anninski, T. Shiganova, Abolgaseem Roohi, M. Roushan-Tabari, M. Yousef- fyan, M.T. Rostamian, H. Rostami, and H. Negarestan. 2004. Physiological characteristics of the ctenophore Beroe ovata in the Caspian Sea water. Marine Ecology Progress Series 266:111-121.

Kideys, A.E., N. Soydemir, G. Ekingen, E. Eker, V. Vladymyrov, and N. Kochisarli. In press. Phytoplankton distribution in the Caspian Sea during March 2001. Hydrobiologia.

Konsulov, A.S. and L.T. Kamburska. 1998. Ecological determination of the new ctenophora - Beroe ovata invasion in the Black Sea. Oceanology [Bulgaria] 2:195-198.

Kovalev, A.V. and S.A. Piontkovski. 1998. Interannual changes in the biomass of the Black Sea gelatinous zooplankton. Journal of Plankton Research 20:13771385.

Kremer, P. 1979. Predation by the ctenophore Mnemiopsis leidyi in Narragansett Bay, Rhode Island. Estuaries 2:97-105.

Kremer, P. and S. Nixon. 1976. Distribution and abundance of the ctenophore, Mnemiopsis leidyi in Narragansett Bay. Estuarine and Coastal Marine Science 4:627-639.

Mutlu, E. 1999. Distribution and abundance of ctenophores, and their zooplankton food in the Black Sea. II. Mnemiopsis leidyi. Marine Biology 135:603613.

Mutlu, C. 2000. Characteristics of anchovy populations (Engraulis encrasicolus, Linnaeus 1758) and application of analytical methods in stock estimate. Ph.D. Thesis, Karadeniz Technical University, Trabzon, Turkey, 112 pp.

Niermann, U., F. Bingel, A. Gorban, A.D. Gordina, A.C. Gücü, A.E. Kideys, A. Konsulov, G. Radu, A.A. Subbotin, and Z.E. Zaika. 1994. Distribution of anchovy eggs and larvae (Engraulis encrasicolus Cuv.) in the Black Sea in 1991-1992. ICES Journal of Marine Science 51:395-406.

Purcell, J.E. and M.B. Decker. 2005. Effects of climate on relative predation by scyphomedusae and ctenophores on copepods in Chesapeake Bay during 1987-2000. Limnology \& Oceanography 50(1):376-387

Reeve, M.R., M.A. Walter, and T. Ikeda. 1978. Laboratory studies of ingestion and food utilization in lobate and tentaculate ctenophores. Limnology and Oceanography 23(4):740-751.

Shiganova, T.A., A.M. Kamakin, O.P. Zhukova, V.B. Ushivtzev, A.B. Dulimov, and E.I. Musayeva. 2001. The invader into the Caspian Sea ctenophore Mnemiopsis and its initial effect on the pelagic ecosystem. Oceanology 41:517-524.

Shiganova, T.A., H.J. Dumont, A. Mikaelyan, D.M. Glazov, Yu.V. Bulgakova, E.I. Musayeva, P.Y. Sorokin, L.A. Pautova, Z.A. Mirzoyan, and E.I. Studenikina. 2004. Interaction between the invading ctenophores Mnemiopsis leidyi (A. Agassiz) and Beroe ovata Mayer 1912, and their influence on the pelagic ecosystem of the northeastern Black Sea. Pp. 33-70 in Aquatic invasions in the Black, Caspian and Mediterranean Seas, H. Dumont, T. Shiganova and U. Niermann, eds. Kluwer Academic Publishers, Dordrecht, The Netherlands.

Vinogradov, M.E., E.A. Shushkina, E.I. Musaeva, and P.Yu. Sorokin. 1989. A new acclimated species in the Black Sea: The ctenophore Mnemiopsis leidyi (Ctenophora: Lobata). Oceanology 29:220-224. 